\title{
An analysis of Turkey's telecommunications sector's social responsibility practices online
}

\author{
Emel Ozdora-Aksak* \\ Bilkent University, Ankara, Turkey
}

\section{A R T I C L E I N F O}

\section{Article history:}

Received 15 July 2014

Received in revised form

18 September 2014

Accepted 19 January 2015

\section{Keywords:}

Corporate social responsibility

Public relations

Organizational identity

Legitimacy

Telecommunications sector

Social media

\begin{abstract}
A B S T R A C T
Rooted in social identity theory, this exploratory study focuses on Turkey's four largest telecommunications companies (Turkcell, Türk Telekom, Avea, and Vodafone) to determine how public relations and corporate social responsibility practices help construct organizational identity. To achieve its aim, the study performs a thematic content analysis of the companies' corporate websites and social media accounts. Study results reveal that, in addition to focusing on their core business functions, telecommunications companies in Turkey try to create value and construct a legitimate identity by emphasizing community benefits and their superiority vis-à-vis their competitors. This study also demonstrates that companies' CSR activities play a crucial role in constructing organizational identity and gaining legitimacy.
\end{abstract}

(C) 2015 Elsevier Inc. All rights reserved.

\section{Introduction}

Public relations, which helps organizations establish long-term relationships with their clients, is one of the most important organizational communication functions. Public relations activities are required to inform consumers about an organization, its identity, and its activities. While achieving communication goals and making decisions, organizations should also take into account their clients' opinions, ethical concerns, and social responsibility considerations (Grunig, 2006). Communicating corporate social responsibility (CSR) activities to stakeholders is necessary if an organization wants to benefit from CSR initiatives and differentiate itself from its competitors (Smith \& Alexander, 2013). The public relations literature does not contain extensive studies from Turkey, so this study aims to close that gap by portraying a case that reveals the public relations scene in that country. This research focuses on the role of public relations in constructing organizational identity by bringing together public relations studies and organizational studies through qualitative and quantitative techniques to understand this relationship in detail. The study also tries to bring a different theoretical perspective to the field of public relations though its focus on social identity theory.

\footnotetext{
* Tel.: +90 3122901061.

E-mail address: emelozdora@gmail.com
} 


\section{Literature review}

\subsection{Organizational identity, corporate social responsibility and public relations}

Organizational identity helps people identify and differentiate the organization from others. Public relations is one of the major organizational communication tools used to construct organizational identity and communicate this identity to relevant stakeholders. Public relations may help an organization in creating a positive public perception and a strong reputation, and in gaining public support. Good public relations helps build, nurture, and strengthen mutually beneficial relationships between an organization and the public (Bruning \& Ledingham, 2000; Ki \& Hon, 2007).

Stakeholders, especially customers, "tend to be more satisfied with companies that are more socially responsible, perceive these companies more favorably (in terms of corporate reputation and brand equity), and reward these firms" (Hsu, 2012, p. 198) by buying their products. Communicating about CSR activities has become an important part of organizational communication efforts because an organization's reputation and legitimacy strongly depend on those initiatives (Verboven, 2011). Corporate websites are increasingly used to communicate an organization's CSR efforts (Verboven, 2011) and as an interactive tool to engage with stakeholders (Bonsón \& Ratkai, 2013). As Pavitt (2012) argued, organizations must make effective use of improving communication technologies and "recognize that they can no longer evade their responsibility to act ethically and responsibly as. . true corporate citizen[s]” (p. 25).

\subsection{Public relations and the use of social media}

Shortly after social media gained popularity for social networking purposes, communication scholars realized its potential for organizational communication (Bonsón \& Ratkai, 2013). The Internet and social media are studied by public relations professionals for the interaction and engagement opportunities they create between organizations and the public, such as asking questions, sharing content, and/or having conversations (Alikilic \& Atabek, 2012; Bonsón \& Ratkai, 2013; Hill \& White, 2000; Ye \& Ki, 2012). The use of the Internet and social media has evolved similarly in Turkey. Today, Turkey is a major user of social media, with 45 percent of the population (35 million) accessing the Internet, making the country the fifth-largest Internet user in Europe (Internet World Stats, 2012). According to Comscore (2011), social media is one of the most popular reasons for Internet use in Turkey. In fact, Turkey has the third-largest population of Facebook users in the world (Alikilic \& Atabek, 2012).

This study aims to reveal how the telecommunications sector in Turkey uses corporate websites and social media accounts as part of their public relations strategies. Accordingly, the first research question focuses on revealing which themes and theme categories are used by the four largest telecommunications companies in Turkey to construct their organizational identities on their websites and social media accounts. The research also aims to reveal the role of CSR initiatives for identity construction; thus the second research question tries to understand the role of corporate social responsibility in the online identity construction of Turkey's four largest telecommunications companies.

\section{Methodology}

This exploratory research analyzes website content to study how organizations define themselves and communicate their distinctive characteristics to create a positive identity. Content analysis is a common research method for examining information provided by businesses and institutions (Bonsón \& Ratkai, 2013; Ettredge, Richardson, \& Scholz, 2001; GallegoAlvarez, Rodriguez-Dominguez, \& Garcia-Sanchez, 2011; Waters, Tindall, \& Morton, 2010). The language used on the websites of Turkey's four largest telecommunications companies to communicate organizational identity is the main focus of the study. This research also aims to understand influence of CSR activities on organizational identity construction.

\subsection{Website analysis}

The use of online public relations has become a common way for organizations to engage with their stakeholders. Research reveals that larger firms tend to have a stronger CSR engagement (Campbell, 2007; Luo \& Bhattacharya, 2006), thus this study focuses on Turkey's four largest telecommunications companies, who provide service to a significant number of people, assuming that CSR communication would be prevalent among them. Textual data were collected from the About Us, History, Mission and Vision, and Corporate Social Responsibility sections of each company's website.

\subsection{Social media analysis}

The posts and photos shared on the studied telecommunications companies' social media accounts (Facebook and Twitter) between March and May 2014 were collected in a word processing document and analyzed quantitatively and qualitatively. The number of posts and photos was counted to reveal and compare the social media use of different companies. The content of the posts was then analyzed to reveal themes utilized by each company and to understand how many and what kinds of CSR activities are mentioned on social media. The content of social media and websites was analyzed to determine main themes and answer the research questions. 
Focusing on recurring issues and concepts expressing distinctive characteristics of each telecommunications company helped identify dominant themes. The researcher engaged a colleague to assist with the coding process to ensure it was as objective and reliable as possible. The researchers first identified themes separately, and then compared and combined their findings. Final themes were mutually agreed upon by both researchers and then categorized under comprehensive headings to identify dominant theme categories. Next, the researchers compared the categories to determine the unique positioning of each company and its CSR initiatives. This analysis also helped reveal variations in each company's use of identity characteristics and CSR activities in its identity construction and communication. To make comparisons between companies more meaningful, only themes emphasized by at least two companies were included in the analysis. Following section discusses the findings.

\section{Results}

\subsection{Overview of Turkey's four largest telecommunications companies}

As the oldest telecommunications company in Turkey, Türk Telekom is the industry pioneer. Since its privatization in 2005, Türk Telekom has been the forerunner in integrated telecommunications services and provides service to 15.8 million landlines, 6.7 million ADSL lines and 11.8 million GSM users. Türk Telekom owns 89.99 percent of Avea's (Turkey's thirdlargest telecommunications company) total shares (Türk Telekom, 2014). Turkcell, Turkey's first GSM service provider, was established in 1994 and grew rapidly to become a national and regional market leader. Turkcell's shares started trading on the Istanbul Stock Exchange and the New York Stock Exchange in July 2000, making Turkcell the first and only company to be traded on the latter. Turkcell has 3G agreements in 110 countries and GPRS roaming agreements in 165 countries, making the company one of the top global players in the industry (Turkcell, 2014). Established in Turkey in 2006, Vodafone Turkey is part of Vodafone Group, which is one of the largest global telecommunications companies. Vodafone Turkey is the second-largest player in the Turkish market with close to 20 million users (Vodafone, 2014). Avea, Turkey's youngest and most innovative mobile service provider, was established in 2004 and reached 14.5 million users by the end of 2013, bringing heavy competition to Turkey's telecommunications sector. Avea is mostly owned by Türk Telekom, with İs Bank holding the remaining 10.01 percent of its shares (Avea, 2014).

\subsection{Themes derived from the website analysis}

A quick glance at the results reveal that two companies, Türk Telekom and Turkcell, stand out with the number and variety of themes emphasized on their websites. Avea and Vodafone fall behind because they do not emphasize any particular theme to help them construct a unique identity and differentiate themselves from the sector's major actors. (It should be reiterated, however, that Vodafone Turkey is still young as it was established only 8 years ago, much later than Türk Telekom and Turkcell, and Türk Telekom owns almost 90 percent of Avea.) These four companies are significantly different in terms of the themes they use to construct their identities, which answers the study's first research question. Türk Telekom has strategically differentiated itself by focusing on the importance of CSR, in addition to products and services, partnership/mergers, and customer orientation. Turkcell heavily emphasizes having an international presence but it also stresses growth and its products and services. Vodafone does not use a specific theme to differentiate its identity, and Avea focuses on self-glorification, which might be related to being owned by Türk Telekom and trying to stand out via this connection.

The analysis revealed that all companies emphasize the themes: products and services, self-glorification, qualified personnel, and investments. While Türk Telekom and Turkcell heavily emphasize their products and services, Avea and Vodafone touch on this theme only briefly. The second common theme that emerged out of the analysis was self-glorification, a term the researchers used to code keywords such as largest, pioneer, leader, top, best, first and/or most preferred. The two other themes used by all four companies were qualified personnel and investment size, which show that all companies attach importance to growth and development.

The second research question focused on understanding the significance of CSR in the organizational identity construction process. The results revealed that all four companies communicate their CSR initiatives to some extent for constructing their identities and differentiating themselves. All companies engage in CSR activities in the fields of education and inclusiveness, and they try to communicate these initiatives to their audiences. The dominant CSR themes used on Turkcell's CSR webpage are sports, entrepreneurship, and employee volunteerism, and Türk Telekom focuses mainly on education. Avea and Vodafone, however, exhibit no CSR themes on their websites.

\subsection{Themes derived from social media analysis}

The study's social media analysis focused on March, April, and May 2014 and examined the entire content of the four telecommunications companies' official Facebook and Twitter accounts (all organizations use both media), studying and coding a total of 718 posts and tweets. First, each company's accounts were studied separately, and then they were compared with the other companies' accounts to determine similarities and differences between companies' social media preferences. The author made the following findings: (1) the content on a company's Facebook and Twitter accounts is similar to each other; (2) all companies' Facebook and Twitter accounts are active; (3) and all organizations use Twitter more often: each 
company's tweets were double, and in some cases almost triple, its number of Facebook posts. The results also revealed that organizational use of social media in Turkey is still in the development stage because companies had week-long or even 10-day breaks between posts or tweets.

The major themes used by all four companies on their social media accounts were: discounts/gifts/deals, engagement/multimedia/contests, general information, products and services, and self-glorification to emphasize superiority in comparison to competitors. The companies' social media content is different from their website content. This difference seems understandable when the daily and interactive nature of social media is considered. However, there were some recurring themes. First, all companies commonly share information on new products and services on social media. Second, the superiority theme is more evident on social media than websites, especially for Turkcell and Türk Telekom, who repeatedly comment on being the best, highest, strongest, and/or first. Avea and Vodafone also try to emphasize their superiority, but not as often.

Due to its open and interactive nature, social media enables engagement opportunities with the public by asking openended questions, sharing videos (by companies and users), and offering contests. Avea seems to be the leader in social media activities, with the most engaging and interactive account: almost 70 percent of it is devoted to interactive opportunities. Another difference between companies' social media accounts and their websites is the former's focus on discounts, gifts, and special deals; such offers are not as prevalent on the websites. The companies also share industry or company-specific news, which was coded as general information. Although these types of posts/tweets are not common (except Turkcell), the researcher believes that the companies still wish to impart some of this information on their social media accounts to share content on a daily basis and create the impression of a more active account.

CSR is also a hot topic on social media. All four companies proudly share their CSR initiatives in public health and sports, education, arts and culture, inclusiveness, and social sensitivity. The theme inclusiveness was pinned and preferred by the researcher to refer to issues the companies called helping the disadvantaged, which included persons with disabilities, persons from low-income brackets, and women. The term inclusiveness is more positive, and more constructive, as it signifies a solution rather than a problem. One CSR theme is apparent on all companies' social media accounts: social sensitivity. The researcher pinned this theme to code posts and tweets that included current social happenings, such as special days and events such as Mother's Day or Children's Day, and/or social issues or problems, such as the Soma mining disaster of May 13, 2014, in which over 300 miners died, and which found a place on the global news.

As evident from the website analysis, each company tries to have a different CSR focus and to differentiate itself from its competitors; companies' social media accounts highlight this difference even further. Türk Telekom heavily communicates about public health and sports as part of its CSR initiatives because it is the main sponsor of three major Turkish soccer teams. Turkcell focuses on inclusiveness, with many campaigns and activities to support persons with disabilities, women's empowerment, and education. Vodafone emphasizes social sensitivity and, to a lesser degree, sports, as it is sponsoring a stadium construction for one of the top teams in the soccer league. Avea has a weak CSR component on social media, focusing only on issues with social sensitivity.

\section{Discussion and conclusions}

Organizations are increasingly using online communication methods to impart their identities and engage with stakeholders. The organizational identity and CSR literature makes use of social identity theory and the organizational identification construct to explain the influence of CSR on identification. Studies with this theoretical background highlight CSR initiatives' influence on reputation, consumer-company identification (Bhattacharya \& Sen, 2003), and customer satisfaction (Luo \& Bhattacharya, 2006). Results reveal that Turkey's telecommunications companies emphasize CSR initiatives on their websites and social media accounts to connect with their stakeholders.

After all themes were identified, they were classified and categorized to determine the identity construction pattern in Turkey's telecommunications sector. In addition to communicating core business functions, such as qualified personnel, products and services, and customer orientation, the companies presented their extensive impact and development agendas, future orientation, their superiority, and how they behave ethically. This finding reveals that as much as core business functions are important for identity construction, so too are functions that emphasize community support and superiority. As a result, it could be argued that these companies try to create value, differentiate themselves, and construct a legitimate organizational identity mainly through highlighting themes beyond their core business functions. This practice allows organizations to transcend their pragmatic function to create an ethical identity and gain legitimacy in the eyes of the public (Özen \& Yeloğlu, 2006). The study results highlight the critical role played by CSR activities in identity construction. CSR, coded under being ethical, is utilized by all telecommunications companies for identity construction and its communication. This can be explained by companies' aspirations to be good corporate citizens and contribute to community and affirms that CSR is key to building a strong organizational identity and gaining legitimacy.

\subsection{Recommendations for practitioners}

Based on social identity theory, identity construction can be considered a continuous process whereby an organization tries to construct its unique identity and communicate it to stakeholders through communication activities and tools. Consequently, themes emphasized by organizations to achieve these goals and to differentiate themselves from their competitors 
are very important, and this process should be managed strategically to gain a competitive advantage. Public relations and communication practitioners should study the communication materials of companies in their industry and find ways to make their company's identity unique.

\subsection{Study limitations and areas for future research}

In this study, the researcher tried to provide a different perspective on the public relations literature by providing an overview from Turkey, a country that receives little coverage. One of the study's limitations is its narrow focus (four companies and one sector); the study could be enhanced by adding evaluations from other sectors and providing a multi-sectoral comparison. In addition, the unit of analysis used for the study relies on secondary data (websites and social media accounts); this aspect could be enhanced by providing primary data such as in-depth interviews with and/or surveys of employees and/or external stakeholders (e.g. customers). However, the limitations of this study arise from its exploratory scope, and the researcher hopes that it may provide ideas and inspiration for future research.

\section{References}

Alikilic, O., \& Atabek, U. (2012). Social media adoption among Turkish public relations professionals: A survey of practitioners. Public Relations Review, 38, 56-63.

Avea. (2014). About Avea. Retrieved from: http://www.avea.com.tr/en/sta/hakkinda/hakkinda/aveahakkinda.shtml?pagemenu=hakkinda.hakkinda

Bhattacharya, C. B., \& Sen, S. (2003). Consumer-company identification: A framework for understanding consumers' relationships with companies. Journal of Marketing, 67(2), 76-88.

Bonsón, E., \& Ratkai, M. (2013). A set of metrics to assess stakeholder engagement and social legitimacy on a corporate Facebook page. Online Information Review, 37(5), 787-803.

Bruning, S. D., \& Ledingham, J. A. (2000). Perceptions of relationships and evaluations of satisfaction: An exploration of interaction. Public Relations Review, 26, 85-95.

Campbell, J. L. (2007). Why would corporations behave in socially responsible ways? An institutional theory of corporate social responsibility. Academy of Management Review, 32, 946-967.

Comscore. (2011). Turkey in the global Internet and the future of online measurement. Presentation retrieved on 18 March 2013, from http://www. comscore.com/Insights/Presentations_and_Whitepapers/2011/Turkey_in_the_Global_Internet_and_The_Future_of_Online_Measurement

Ettredge, M., Richardson, V., \& Scholz, S. (2001). The presentation of financial information at corporate web sites. International Journal of Accounting Information Systems, 2(3), 14-68.

Gallego-Alvarez, I., Rodriguez-Dominguez, L., \& Garcia-Sanchez, I. (2011). Information disclosed online by Spanish universities: Content and explanatory factors. Online Information Review, 35(3), 360-385.

Grunig, J. E. (2006). Furnishing the edifice: Ongoing research on public relations as a strategic management function. Journal of Public Relations Research, $18(2), 151-176$.

Hill, L. N., \& White, C. (2000). Public relations practitioners' perception of the World Wide Web as a communication tool. Public Relations Review, 26, 31-51.

Hsu, K. T. (2012). The advertising effects of corporate social responsibility on corporate reputation and brand equity: Evidence from the life insurance industry in Taiwan. Journal of Business Ethics, 109, 189-201.

Internet World Stats. (2012). Top 20 Countries with Highest number of Internet Users - June 30, 2012. Retrieved 18 March 2013, from http://www. internetworldstats.com/top20.htm

Ki, E. J., \& Hon, L. C. (2007). Testing the linkages among the organization-public relationship and attitude and behavioral intentions. Journal of Public Relations Research, 19, 1-23.

Luo, X., \& Bhattacharya, C. B. (2006). Corporate social responsibility, customer satisfaction, and market value. Journal of Marketing, 70(4), 1-18.

Özen, Ş., \& Yeloğlu, H. O. (2006). Bir örgüt kimliği olarak 'Holding’ adının inşası ve aşınması: Eşanlı kurumsallaşma ve çözülme üzerine bir model önerisi. Yönetim Araştırmaları Dergisi, 6(1-2), 45-84.

Pavitt, H. (2012). No place to hide: New technological advances in Web 2.0 and social media may force organisations to improve their corporate social responsibility. Social Alternatives, 31(2), 22-26.

Smith, K. T., \& Alexander, J. J. (2013). Which CSR-related headings do Fortune 500 companies use on their websites? Business Communication Quarterly, $76(2), 155-171$.

Türk Telekom. (2014). About Türk Telekom. Retrieved from: http://www.turktelekom.com.tr/tt/portal/About-TT/Company-Profile/About

Turkcell. (2014). History. Retrieved from: http://www.turkcell.com.tr/en/aboutus/company-overview/history

Verboven, H. (2011). Communicating CSR and business identity in the chemical industry through mission slogans. Business Communication Quarterly, 74, 415-431.

Vodafone. (2014). Tarihçe. Retrieved from: http://www.vodafone.com.tr/VodafoneHakkinda/tarihce_home.php?default_id=hakkimizda-tarihce

Waters, R. D., Tindall, N. T. J., \& Morton, T. S. (2010). Media catching and the journalist-public relations practitioner relationship: How social media are changing the practice of media relations. Journal of Public Relations Research, 22(3), 241-264.

Ye, L., \& Ki, E. J. (2012). The status of online public relations research: An analysis of published articles in 1992-2009. Journal of Public Relations Research, 24(5), 409-434. 